\title{
Die Afrikaanse vrou se posisie in kerk en samelewing: evolusie van die Nederduitse Gereformeerde Kerk se standpunt
}

\author{
J.A. du Pisani \\ Departement Geskiedenis \\ Potchefstroomse Universiteit vir $\mathrm{CHO}$ \\ POTCHEFSTROOM
}

\begin{abstract}
The Afrikaans woman in church and society: evolution of the viewpoint of the Dutch Reformed Church (Nederduitse Gereformeerde Kerk)

The stereotyped view in anti-Afrikaans and feminist circles holds that narrow-minded Calvinism has been a decisive factor in the alleged subservience of Afrikaans women. This article investigates one facel of Afrikaans social life as a starting point for a comparison between the social status of Afrikaans women and that of women in other South African and international communities. The article focuses, against the background of international developments in Christian churches, on the evolution of the official position in the Nederduitse Gereformeerde Kerk (NGK) sometimes referred 10 as the Dutch Reformed Church - the largest Afrikaans church, regarding the slatus of women. Emphasis is placed on the process of admission of women to the special offices of deacon, elder and minister in the NGK. The debate within the NGK on this issue reveals the evolution of thought and values in mainstream Afrikanerdom. The conclusion is reached that a definite shift away from traditionalist fundamentalism towards a more open and less dogmatic approach has taken place in the NGK and that the current sitwation does not reflect such a pietistic submissiveness among Afrikaans women as suggested by feminist studies. However, although theoretically women enjoy equal access to the special offices in the NGK, in practice equality does not exist. In governing bodies of the church women are still hopelessly underrepresented. A steep road has to be climbed before women will attain equality in the church hierarchy.
\end{abstract}

\section{Inleiding: vroueregte in die kontemporêre Suid-Afrikaanse konteks}

Vroue was die grootste wenners in die golf van politieke transformasie wat in die afgelope vyf jaar oor Suid-Afrika gespoel het. Die klem wat tydens die onderhandelingsproses vir 'n nuwe politieke bedeling in Suid-Afrika op menseregte en demokrasie geplaas is, het die deur vir vroue in die land geopen 
om, terwyl die swart meerderheid die juk van rasse-onderdrukking onder apartheid afgooi, ook te begin om die juk van onderworpenheid aan die manlike geslag in 'n patriargale samelewing te verlig.

Vroue-organisasies het die onderhandelingsproses vir 'n nuwe grondwet aangegryp en hulle energiek daarvoor beywer om die kwessie van vroueregte op die politieke agenda geplaas te kry. 'n Nasionale Vrouekoalisie is geskep en het 'n handves vir vroueregte vir voorlegging aan die grondwetskrywende vergadering opgestel (Sunday Tribune, 6.03.94; Beeld, 1.03.94). Tydens die onderhandelingsproses is vroue geakkommodeer deur die insluiting van vroue in die partye se afvaardigings by die Onderhandelingsraad en -forum verpligtend te maak (Du Pisani, 1994:46). Die Onderhandelingsraad se tegniese komitee oor diskriminerende wetgewing het die afskaffing van geslagsdiskriminerende wetgewing aanbeveel (Du Pisani, 1994:55). Verder het die Uitvoerende Oorgangsraad wat die uitvoerende gesag in die voorverkiesingsfase met die Kabinet gedeel het, beskik oor 'n subraad oor die status van vroue om volle deelname vir vroue in die oorgangstydperk te verseker (Du Pisani, 1994:58). Benewens die handves van fundamentele regte waardeur ook vroueregte indirek verskans is, het die Tussentydse Grondwet waarop uiteindelik ooreengekom is, vir 'n Kommissie vir Geslagsgelykheid voorsiening gemaak (Du Pisani, 1994:74). In die 1994-verkiesingsveldtog was vroueregte 'n prominente kwessie, aangesien ongeveer 54\% van die kieserskorps vroue was (Beeld, 16.02.94; Weekend Argus, 19.02.94).

Hierdie gebeure tydens die politieke onderhandelingsproses het 'n merkbare impak op die posisie van Suid-Afrikaanse vroue gehad. Binne enkele jare is hul agterstand by hul susters in Europa en Amerika ten opsigte van vroueregte aansienlik verklein. In die Afrikakonteks het Suid-Afrikaanse vroue die voortou geneem in die stryd om vroueregte. Daar is met mening begin om die wanbalans ten gunste van mans in die politieke lewe en in bestuursposte in die staatsdiens en elders reg te stel. "Pale males" het inderdaad 'n bedreigde spesie geword!

'n Verdere uitvloeisel van die sosiopolitieke transformasieproses was dat die soeklig skerper as ooit op die posisie van die vrou in die verskillende kultuurgemeenskappe in Suid-Afrika geval het. In die media is onder meer in 'n reeks aktualiteitsprogramme op TV 1 indringend gekyk na die vrou se plek in tradisionele swart gemeenskappe, die Moslemgemeenskap, ortodokse Joodse kringe en ook in die Afrikaanse gemeenskap. Hierdie programme het onderstreep dat Suid-Afrika weens sy godsdienstige en kulturele tradisies 'n fundamenteel patriargale samelewing is, maar dat Suid-Afrikaanse vroue geleidelik begin om hulle aan manlike oorheersing te ontworstel.

Teen die agtergrond van hierdie tendense in die Suid-Afrikaanse samelewing het die vraag ontstaan: Hoe onderdanig is die Afrikaanse vrou in vergelyking met 
haar landgenote van ander kultuur- en godsdiensgroepe en in vergelyking met vroue elders in die wêreld?

In 1994 het 'n polemiek in die media ontstaan oor die sosiale posisie van die Afrikaanse vrou. Dit het begin met die verskyning van die Afrikaanse teoloog, Christina Landman, se boek The Piety of Afrikaans Women. Deur 'n analise van die dagboeke van vroue uit verskillende tydperke het Landman tot die gevolgtrekking gekom dat die Afrikaanse samelewing verdeel kan word in 'n dominante manlike kultuur en 'n vroulike subkultuur. Volgens haar is Afrikaanse vroue sosiaal en polities verslaaf deur hul piëteit en die geskiedenis. Selfopoffering is sinoniem met die Afrikaanse vrou: "Afrikaans women ... excelled in self-humiliation and in self-hate to please their demanding male God" (Landman, 1994:118). Landman is van mening dat Afrikaanse vroue nog nie bevry is van hierdie gekondisioneerde onderwerping aan manlike oorheersing nie en sodoende is hulle "disloyal to themselves, to their sex and to the motherhood of God which dwells in them" (Landman, 1994:119).

Landman se uitdagende standpuntinname is deur pleitbesorgers vir vroueregte toegejuig (Beeld, 4.08.94 - Joan Hambidge; Insig, Aug. 1994 - Martie Meiring en Sept. 1994 - Cecile Cilliers), maar haar standpunt is in konserwatiewe Afrikaanse kringe, sowel manlik as vroulik, as byna ketters beskou Verontwaardiging is onder meer uitgespreek oor haar siening dat die Vrouemonument in Bloemfontein - waarna sy in navolging van 'n vroeëre artikel deur Elsie Cloete (1992:50) woedend as 'n "ereksie" verwys het - deur Afrikaanse mans opgerig is om die vrouegeskiedenis in die Tweede AngloBoereoorlog vir hul eie dienstige redes tot martelaarskap te verhef (Die Volksblad, 28.07.94).

Op 13 September 1994 is op die SAUK TV-program "Agenda" 'n dokumentêre program uitgesaai waarin Jeanne Goosen en ander feministiesgesindes te velde getrek het teen die tradisionele neiging van Afrikaanse vroue om hulle gedwee aan manlike oorheersing te onderwerp. Vanuit meer tradisionele Afrikaanse kringe was daar heftige besware teen die eensydigheid van hierdie program waardeur na bewering ' $n$ karikatuur van die moderne Afrikaanse vrou geskep is (briewe in Die Burger, 16.09.94; Die Patrol, 23.09.94; Rapport, 2.10.94; Die Volksblad, 7.10.94). In 'n opvolgprogram op 19 September is 'n aantal prominente Afrikaanse vroue die geleentheid gegee om die ander kant van die saak te stel. Die opvolgprogram het eweneens skerp kritiek uitgelok (briewe in Beeld, 23.09.94)

Die sosiale status van die Afrikaanse vrou het 'n aktuele onderwerp in TVbesprekingsprogramme en in koerant- ell tydskrifartikels geword (Algemene Kerkbode, 14.10.94; Wessels, 1994:32-34). Teenoor feministiese standpunte is manlike chauvinistiese standpunte gestel (Wessels, 1994). In Insig het Daan 
Steyn (1994:12-13) so ver gegaan om te beweer dat die man ontman is in die Westerse kultuur met sy toenemend verwyfde inslag. Volgens hom het vroue reeds die beheer van die kultuur en die godsdiens oorgeneem en is hulle ook besig om die politieke mag te verkry. In die Afrikaanse gemeenskap word hierdie magsverskuiwing syns insiens onder meer weerspieël in vroue se oomame van die diaken- en ouderlingampte in die kerke. Dit lyk dus nie of Steyn en Landman dieselfde vroue ken nie!

Dit sou 'n uitgebreide sosiologiese ondersoek verg om gesaghebbende uitsprake te lewer oor die Afrikaanse vrou se sosiale status. Die opset van hierdie artikel is meer beskeie: dit fokus op 'n enkele, weliswaar belangrike, faset - die grootste Afrikaanse kerk se amptelike standpunte oor die status van die vrou in die kerk en die breër samelewing. Hierdie fokus is ' $n$ respons op die stereotiepe siening vanuit anti-Afrikaanse en feministiese kringe dat die eng uitgangspunte van die Calvinistiese lewensbeskouing 'n deurslaggewende faktor was in die Afrikaanse vrou se beweerde onderdanige status in die gemeenskap.

Daar word veral gekyk na die Nederduitse Gereformeerde Kerk (NGK) se standpunt oor die toelating van die vrou tot die besondere ampte van diaken, ouderling en leraar. Die beredenering van dié omstrede kwessie binne die NGK werp lig op die kerkleiding se opvattings oor die rol van die vrou in die samelewing. In die lig van die toonaangewende rol van die Afrikaanse kerke in die Afrikaanse samelewing weerspieël dié opvattings die heersende waardes onder Afrikaanssprekendes. Verder word die NGK se standpunte vergelyk met dié van Christelike kerke in die res van die wêreld. Die kwessie oor die toelating van vroue tot die leraarsamp was een van die oorheersende strydpunte in Christelike kerke wêreldwyd in die afgelope dekade.

\section{Die internasionale konteks: impak van die vroueregte- beweging op Christelike kerke}

In Geskiedenishandboeke oor die twintigste-eeuse wêreld word die veranderende rol van vroue as een van die kenmerkende tendense en een van die mees rewolusionêre veranderings van hierdie eeu geidentifiseer. Hierdie tendens wat in Westerse lande geinisieer is, het stelselmatig ook na Asië en Afrika versprei. Ontwikkelings wat hiertoe bygedra het, sluit die volgende aspekte in: die toetrede van vroue tot die arbeidsmark weens industrialisering, vroue se toegang tot beter onderwysgeleenthede en die beheer van swangerskappe deur voorbehoedmiddels (Stavrianos, 1990:746-750; Findley \& Rothney, 1990:329332; Wallbank et al., 1981:513-516). Vroue se posisie in die samelewing het in die twintigste eeu inderdaad drasties verbeter in vergelyking met die negentiende eeu. Diskriminasie teen vroue op die politieke, ekonomiese en sosiale terreine het afgeneem. Vroue het stemreg en inspraak in politieke besluitneming verkry. 
In die beroepslewe is gevorder in die rigting van pariteit tussen manlike en vroulike werknemers en het 'n groeiende persentasie vroue tot bestuursposisies gevorder.

Een van die belangrikste uitvloeisels van vroue se veranderende situasie was die opkoms van die vroueregtebeweging en die feministiese ideologie. Die eerste golf van feminisme in die laat $19 \mathrm{de}$ en vroeë 20ste eeu het gewentel om die kwessie van stemreg vir vroue. In die stormagtige sestigerjare het die tweede golf feminisme die wêreld in die vorm van die vrouebevrydingsbeweging getref. Radikale feminisme het op die voorgrond getree en revolusionêre sosiale verandering geëis waardeur patriargie en die seksuele onderdrukking van vroue afgetakel sou word. Tydens die tydperk van konserwatiewe reaksie in die tagtigerjare het die vroueregtebeweging in die minder radikale fase van die postfeminisme inbeweeg. Binne die oorkoepelende feministiese beweging het verskillende tradisies en selfs botsende strominge op mekaar ingespeel. Heywood (1992:219) tipeer die stand van die vroueregtebeweging in die negentigerjare soos volg:

The women's movement has certainly changed, but far from weakening it has continued to expand and broaden. In the 1990s feminist organisations exist in all Western countries and women's groups have developed in the Third World ... Feminism has developed into a distinctive and established ideology, whose ideas and values challenge the most basic assumptions of conventional political thought.

Feminisme se inpak is ook in die Christelike kerke gevoel. Binne die radikale teologiese stroming wat as die bevrydingsteologie of kontekstuele teologie bekend staan, het 'n feministiese teologie ontwikkel. Hierdie teologie was afgestem op die bevryding van die vrou as die oudste onderdrukte wese op aarde, en veral van die swart vrou as die mees onderdrukte van die onderdruktes. Saam met die breër feministiese beweging het die feministiese teologie binne die strukture van die Christelike kerk gestry teen seksisme en diskriminasie en vir die emansipasie van die vrou. Kritiek is uitgespreek teen paternalisme en manlike oorheersing in die samelewing en spesifiek ook in die godsdiens (Van Wyk, 1987:69). In so 'n mate is prominensie in kerklike kringe aan die kwessie van vroueregte gegee, dat die Wêreldraad van Kerke, bekend vir sy neiging tot radikalisme, aan die einde van die tagtigerjare 'n ekumeniese dekade in solidariteit met vroue afgekondig het (Gnanadason, 1994:133-134)

Aan die een kant het kerklike standpunte oor sake soos egskeiding, homoseksualisme, geboortebeperking en aborsie verander. Aan die ander kant het kontroversie binne en tussen kerke ontstaan oor die vraag of vroue tot die bediening toegelaat moes word. Hierdie kontroversie het so 'n omvang en intensiteit aangeneem, dat daarna verwys word as 'n "tweede reformasie" binne 
die Christelike kerke (Ostling, 1992:49). Die eerste Reformasie van die 16de eeu het geen verandering van die vrou se rol in die kerk teweeggebring nie.

Protestantse kerke in die Westerse wêreld het reeds in die vyftigerjare begin om vroue toe te laat om predikante te word. In die daaropvolgende dekades het al meer kerke vroue tot die bediening toegelaat. Tussen 1977 en 1986 het die getal vroulike leraars in die VSA verdubbel tot $8 \%$ van die leraarskorps. In WesDuitsland het die persentasie vroulike predikante van die Evangeliese Kerk tussen 1964 en 1988 van $2 \%$ tot $12 \%$ gestyg (Kerkbode, 17.11.89). Tot onlangs het die meeste Protestantse kerke in Asië, Afrika en Latyns-Amerika nog nie vroulike leraars georden nie (Opocenska, 1989:144).

Die ordening van vroueleraars het nie sonder heftige teenkanting uit konserwatiewe Christelike kringe op alle kontinente plaasgevind nie (berigte hieroor het gereeld gedurende die afgelope aantal jare in Die Kerkbode verskyn; kyk ook Büchner, 1991:1).

Geordende vroueleraars het teenkanting en praktiese probleme ondervind en kon nie maklik tot senior poste vorder nie (Bũchner, 1991:1; Müller, 1994:11) Vroueleraars in alle denominasies word gekonfronteer met unieke probleme: tradisionalistiese vooroordeel, gebrek aan aanvaarding, probleme met gesagsuitoefening. Hulle vind dit moeiliker as hul manlike kollegas om werk te kry, aangesien talle gemeentes huiwerig is om 'n vroueleraar te beroep. In Wesleyaanse kerkgenootskappe in die VSA, wat reeds sedert die 19de eeu vroue in die bediening gebruik, het die persentasie vroulike leraars en evangeliste begin afneem. Hierdie tendens word toegeskryf aan 'n konserwatiewe reaksie teen feminisme (Morgan, 1994:52). 'n Besluit van die Sinode van die Christian Reformed Church in die VSA (1993) om vroue as predikante, ouderlinge en evangeliste te orden, is selfs omgekeer deur die 1994-sinode (Frame, 1994:52).

Binne die Anglikaanse Kerk het ' $n$ hewige stryd oor die toelating van vroue tot die bediening tussen liberaalgesindes en konserwatiewe tradisionaliste gewoed 'n stryd wat in die laat tagtiger- en vroeë negentigerjare met die ordening van die eerste vroulike biskoppe 'n hoogtepunt bereik het (Kerkbode, 29.03.91, 27.09.91, 24.07.92, 29.10.93; Inter Nos, Jun. 1991:47). Weens hul teenkanting teen die toelating van voue to die priesteramp het tradisionalistiese Anglikaanse geestelikes en lidmate by die Rooms-Katolieke Kerk aangesluit. Sodoende het die betreklik konserwatiewe Anglikaanse Kerk 'n meer liberale inslag begin kry (Ostling, 1994:48-49). Die toelating van vroue tot die bediening het die Anglikaanse Kerk se gepoogde toenadering tot die Rooms-Katolieke en RussiesOrtodokse Kerke in die wiele gery (Baktis, 1992:35).

Van die Christelike hoofstroomkerke is dit vandag feitlik nog net die RoomsKatolieke en Oosters-Ortodokse Kerke wat nie vroue tot die bediening toelaat 
nie, maar selfs in hierdie kerke vervul vroue tans funksies wat voorheen slegs deur mans uitgevoer is en is daar groeiende steun vir die bevestiging van vroue as priesters. 'n Toenemende aantal Rooms-Katolieke vroue skryf hulle vir teologiese studies in (Kerkhode, 7.07.89). Die huidige Rooms-Katolieke pous het sy teenkanting teen die toelating van vrouepriesters egter ondubbelsinnig gestel (Moody, 1994:49). Druk op die konserwatiewe Rooms-Katolieke kerkleiers oor hul onversetlike houding ten opsigte van vroueleraars en kwessies soos geboortebeperking en aborsie neem toe (Morrow, 1994:60). In die VSA is 'n Women's Ordination Conference binne die Rooms-Katolieke Kerk gevorm 'n beweging wat oortuig is dat die ordening van vrouepriesters onafwendbaar geword het (Moody, 1994:49).

Die stryd oor die kwessie van vroue in die bediening het verdiep tot 'n fundamentele teologiese dispuut oor die rol wat God vir mans en vroue in sy diens bestem het. Hierdie teologiese dispuut gaan in wese oor botsende interpretasies van die Bybel.

Tradisionaliste, veral in die Rooms-Katolieke en Anglikaanse Kerke, vertolk die feit dat Christus net twaalf mans as dissipels geroep het as die instelling van 'n manlike priesterskap. Volgens die ortodokse Rooms-Katolieke teologie kan slegs mans Christus by die altaar verteenwoordig, omdat $\mathrm{Hy}$ as ' $\mathrm{n}$ manlike persoon mens geword het. Dit impliseer nie noodwendig meerderwaardigheid van die manlike geslag nie. Die tradisionaliste sê hulle erken (soos Christus op aarde gedoen het) vroue se gawes en volle geestelike gelykheid en verwerp die manlike chauvinisme van sommige van die ou kerkvaders, maar hulle wil die onderskeie rolle van die geslagte handhaaf. Hulle sien die aandrang op die oopstelling van die priesteramp vir vroue as leerstellig twyfelagtig en polities gemotiveer.

Anglikane wat die bevestiging van vrouepriesters steun, verwerp die siening dat slegs mans Christus by die altaar kan verteenwoordig. Na hul mening is die belangrike feit dat Christus mens geword het, nie dat Hy 'n man geword het nie (Ostling, 1992:51).

Uitsprake deur die apostel Paulus (1 Kor. 14:33-35; 1 Tim. 2:11-15) oor die vrou se verpligting tot onderdanigheid en stilswye in die erediens word steeds as geldig beskou deur konserwatief- en fundamentalistiesdenkendes in Christelike kerke wat teen vroue se toelating tot die bediening gekant is.

Daarteenoor meen die voorstanders van vroue in die bediening dat hierdie Skrifgedeeltes teen die agtergrond van die posisie van die vrou in die destydse samelewing vertolk moet word en nie meer letterlik op die modeme kerk van toepassing is nie. Volgens hulle word die taak van die Christelike kerk benadeel indien vroue, die helfte van die lidmate, verhinder word om hul Godgegewe 
Die Afrikaanse vrou se posisie in kerk en samelewing: evolusie van die NGK se standpunt

gawes ten volle te gebruik (Opocenska, 1989:144; Ostling, 1992:51; Morrow, 1994:60)

Gereformeerde feministiese teoloë wys daarop dat negatiewe persepsies oor seksualiteit in die Christelike tradisie, wat die vrou se rol in die kerk inhibeer, nie in die vroeë Christelike kerk bestaan het nie, maar via Griekse filosofiese invloede op die ou kerkvaders die kerk binnegedring het (Opocenska, 1989:144). Hulle meen dat Calvyn, hoewel hy versigtig was om praktiese reelings oor die posisie van die vrou in die kerk neer te lê, 'n visie van Christelike vryheid vir vroue gehad het (Jane Dempsey Douglass, Women. Freedom and Calvin, aangehaal in Opocenska, 1989:145).

Onderskeid word in die feministiese teologie gemaak tussen "sagte" (reformistiese) feministe wat die Christelike godsdiens bloot van patriargie wil reinig en "harde" (radikale of rewolusionêre) feministe wat hulle verset teen 'n manlike teologie, 'n manlike kerk en 'n manlike God en daarom selfs die Bybel weens sy androsentriese simbole en patriargale inslag verwerp (Van Wyk, 1987:69).

Radikale feministiese teoloë gaan verder as eise om die oopstelling van die priesteramp. Hulle wil tradisionele beskouings oor God verander en wegdoen met die beskouing van God as manlik. Hulle wil die patriargale teologiese model aftakel deur middel van 'n sistematiese rekonstruksie van religieuse simbole (Ferreira, 1993:4). Volgens sekere feministiese teoloë het manlike metafore in die Bybel en 'n manlike Godsbeeld 'n kondisionerende invloed op die samelewing waardeur patriargie versterk word: "If God is male, then the male is god" (Mary Dale aangehaal in Van Wyk, 1987:72). Daarom wil hulle manlike metafore met neutrale of dubbele of vroulike beeldspraak vervang (Van Wyk, 1987:72-74).

In verskillende Christelike denominasies is daar al vir etlike jare bewegings om die teks van gesangeboeke en selfs die Bybel te "suiwer" van eksklusief manlike verwysings na God. So byvoorbeeld het die National Council of Churches in die VSA, wat 40 miljoen Protestantse en ortodokse Christene verteenwoordig, in die tagtigerjare 'n omstrede nuwe weergawe van uitgesoekte Bybeltekste laat publiseer waaruit manlike aanspreekvorme vir God verwyder is (Kerkbode, 16.11.83). Bybelvertalers het voor die vraag te staan gekom of die eksplisiete patriargale taalvorm van die Bybel nie ter wille van duidelikheid geherformuleer kan word sonder om die grondteks te verdraai nie. 'n Nuwe uitgawe van die Good News Bible het enkele jare gelede in die VSA verskyn - 'n uitgawe wat meer "vrouevriendelik" is, maar nie die inhoud van die Bybel geweld aandoen nie. Dit is ook deur die Bybelgenootskap van Suid-Afrika as ' $n$ baanbrekerswerk op die gebied van die Bybelvertalingswetenskap verwelkom (Kerkbode, 
15.10.93). Heel onlangs het Oxford University Press 'n opspraakwekkende gefeminiseerde Bybelvertaling die lig laat sien.

Revolusionêre feministiese teoloë se uitgangspunt is: "God does not have gender, and there are a number of ways God can be addressed without calling God a he or a she" (Ostling, 1992:52). Tradisionaliste sien die verandering van tekste as 'n poging om die Bybel te herskryf en daarvan 'n manifes vir feminisme te maak (Kerkbode, 16.11.83). Hulle verwerp die feministe se vermyding van manlike terme as dualisties en selfs heidens. Volgens hulle omvat God manlike en vroulıke eienskappe, maar is Hy nie tweeslagtig nie: "If you change the language of the liturgy and prayers and feminize it, you're ultimately changing the religion" (Ostling, 1992:52).

Pogings om die kerk van sy patriargale inslag te bevry grens soms aan die absurde. In Australië het die Uniting Church opdrag gegee dat 'n nuwe weergawe van Da Vinci se beroemde skildery, "Die laaste Nagmaal", gemaak moet word, sodat ook vroue ingesluit word (Kerkbode, 16.07.93).

Daar het selfs 'n separatistiese "Women-Church"-beweging, 'n New Age vermenging van feministiese, ekologiese, neo-heidense en Christelike elemente tot stand gekom. In sommige gevalle het feministiese teoloë die konsep van 'n monoteistiese vadergod vervang met ' $\mathrm{n}$ terugkeer na die godinne van die antieke politeïsme (Van Wyk, 1987:72). By 'n ekumeniese konferensie in 1993 te Minneapolis in die VSA, gehou deur Christelike hoofstroomkerke in samewerking met die WRK, is die "godin Sophia" tot groot ontsteltenis van tradisionaliste aanbid (Cyre, 1994:74). Beswaar is gemaak dat feminisme tot godsdiens verhef word (Kersten, 1994:24). Sulke afwykende strominge het daartoe bygedra dat tradisionaliste die feministiese teologie sien as 'n menslike poging om die Christendom omver te werp: "It's not about advancing women in positions in the church. It's about a complete change in theology" (Donna Steichen in Ungodly Rage aangehaal in Ostling, 1992:50).

Die feministiese teologie het in die afgelope jare ook in Suid-Afrika inslag gevind. Onder beskerming van die Instituut vir Kontekstuele Teologie is byeenkomste gereël om vanuit die vrou se perspektief oor die teologie te besin (Inter Nos, Jun. 1989:41). Aansluiting is gevind by die breër stroom van die bevrydingsteologie. Feministiese teoloe in Suid-Afrika se oogmerke is om die kerk te stroop van seksistiese vooroordele en om toe te sien dat vroue as gelykes in die kerklike hiërargie aanvaar word. Sodoende sal vroue 'n gelyke stem in die kerklike besluitneming en bestuur kry. Op die breër sosiale terrein beveg feministiese teoloẻ alle vorms van uitbuiting en onderdrukking en werk hulle vir 'n sosiale orde waar mans en vroue gelyk behandel word (Inter Nos, Jun. 1989:43). 
In Suid-Afrika staan die feministiese teologie in sy kinderskoene. Tydens 'n onlangse besoek aan Suid-Afrika het prof. Elizabeth Schüssler-Fiorenza (1994/1995:13) van Harvard Universiteit se teologiese skool 'n pleidooi gelewer vir meer navorsing deur vroue vanuit 'n feministiese perspektief oor die sosiopolitieke aspekte van geslagsrolle in die godsdiens in Suid-Afrika

Vanuit 'n nie-feministiese perspektief moet erken word dat feministiese teoloě in die afgelope tyd 'n belangrike bydrae tot teologiese vernuwing in die Christelike kerke gelewer het. Hul bevraagtekening van tradisionalisme en hul dikwels uitdagende houding het onteenseglik lewendige debat oor die posisie van vroue in die kerk gestimuleer. Deur hul toedoen is weggedoen met sekere uitgediende patriargale gebruike in die kerk. Van praktiese gelykheid tussen mans en vroue in Christelike kerke is daar egter steeds nie sprake nie.

In hoe 'n mate is die Afrikaanse gemeenskap, tradisioneel konserwatief en sterk patriargaal, deur feministiese invloede in die buiteland en Suid-Afrika geraak?

\section{Eerste stap deur die NGK: vroue toegelaat tot die amp van diaken}

Die gebeure in die NGK rondom die oopstelling van die ampte vir vroue reflekteer 'n gemeenskap wat hom probeer ontworstel aan uitgediende praktyke in 'n patriargale sisteem wat nie meer aan die praktiese eise en morele waardes van 'n veranderende omgewing voldoen nie.

Tradisioneel het die NGK nie alleen die patriargale aard van die Afrikaanse gemeenskap weerspieël nie, maar ook sy lidmate ten gunste van patriargie gekondisioneer. Dit is gedoen op grond van die sogenaamde skeppingsbeginsel wat ook deur Calvyn onderskryf is. Hiervolgens beklee die man as die eersgeskapene die primêre gesagsposisie in die samelewing. Hy is die "hoof" van die vrou in die huwelik. Daarteenoor is die vrou onderworpe aan die man en mag sy nie oor die man heers nie. Hierdie interpretasie is deur die eeue deur die Christelike Kerk as normatief vir alle samelewingsterreine beskou. Versorging, binne die gesin en ook binne die kerk, is gesien as die hoofkenmerk van die vrou se aard. Dié tradisionele Christelike beskouing het die vrou se vryheid beperk en haar verhinder om haar regmatige plek in die kerk en die samelewing in te neem (Büchner, 1991:7).

Ironies genoeg en tipies van die sterk patriargale inslag van die Afrikaanse gemeenskap is die inisiatief om vroue tot die besondere ampte in die NGK toe te laat deur mans geneem. Dit was in ooreenstemming met die beginsel wat in sekere gereformeerde kringe onderskryf word dat die verantwoordelikheid om onreg in die samelewing uit te skakel nie by die verontregte party nie, maar by die bevoorregtes berus (Van Rensburg, 1987:128-130). In die verslae van die NGK 
se Vrouediens, wat by sinodesittings gedien het, word kwalik na die kwessie van vroue in die ampte verwys.

Versoeke vir die herstel van die Nuwe-Testamentiese diakones in die NGK dateer van die veertigerjare. Die gedagte was aanvanklik dat diakonesse, wat nie volwaardige diakens sou wees nie, veral in stedelike gemeentes 'n hulpdiens kon verrig deur alleenlopende dameslidmate in woonstelle en koshuise te besoek. In die vyftigerjare is 'n diakonessehulpdiens met die oog op armsorg ingestel (Nadel, 1985:29-31).

Vanaf die sestigerjare het praktiese oorwegings tot prinsipiële herbesinning in die NGK oor die vrou in kerklike ampte gelei. Die milieu waarbinne die kerk gefunksioneer het, het verander: vroue het die beroepswêreld toenemend betree, meer as die helfte van alle Protestantse kerke wêreldwyd het vroue reeds tot die besondere ampte begin toelaat en in die NGK self het die "nie-amptelike" diensleweringsfunksies deur vroue (barmhartigheidsdiens, sendingwerk, evangelisasie, kategese, ens.) uitgebrei. Vroue het toenemend 'n leidende rol in die NGK begin speel (Nadel, 1985:1, 42).

Die NGK se bediening op geestelike en materiële gebied het begin skade ly deurdat ' $n$ toenemende getal kerkraadsvakatures nie gevul kon word nie. Weens die mannekragtekort was optimale huisbesoek deur ouderlinge en dankofferinsameling deur diakens nie meer moontlik nie. Die praktiese oplossing was om vroue, wat $50 \%$ van die kerk se lidmate en potensiële werkkragte uitgemaak het, aan te wend in die besondere ampte. Voordat dit gedoen kon word, moes kerkrade, ringe, streeksinodes en uiteindelik die Algemene Sinode, as die hoogste besluitnemende liggaam in die NGK, eers besluit oor die prinsipiële regverdigbaarheid daarvan. Hierdie besluitnemingsproses sou 'n kwarteeu duur. Eksterne en interne invloede het op die besluitnemende teoloë, predikante en kerkraadslede ingewerk - 'n proses wat lig werp op die veranderinge wat in hierdie tydperk in die Afrikaanse gemeenskap plaasgevind het.

Die proses het begin toe die Midde-Afrikaanse Sinode die Algemene Sinode van die NGK versoek het om die kwessie oor die vrou in kerklike ampte deur 'n studiekommissie te laat ondersoek. Op aanbeveling van die Tydelike Kommissie vir Algemene Sake is die saak deur die Algemene Sinode van 1966 na die Kommissie vir Leer en Protestantse Aksie (KLPA) verwys (Handelinge, 1966:387, 455, 556).

Dié kommissie het by die Algemene Sinode van 1970 in die lig van tekste soos 1 Korintiërs 14:34-35 en 1 Timoteus 2:11-12 aanbeveel dat die besluit van die Gereformeerde Ekumeniese Sinode (GES) in Amsterdam twee jaar vantevore onderskryf moet word. Die GES-besluit het gelui dat die Bybel leer dat vroue uitgesluit is van die ampte van leraar en ouderling, maar dat kerke na besinning 
oor tekste soos Romeine 16:1, 3, 12 en Fillipense $4: 2,3$ self moes besluit of hulle vroue tot die diakenamp wou toelaat. Die KLPA se mening was dat daar nie 'n afsonderlike diakonesamp ingestel moes word nie, maar dat vroue gebruik kon word vir hulpdienste ten opsigte van barmhartigheidswerk (Agenda, 1970:149150). Die 1970-Sinode het die aangeleentheid na die KLPA terugverwys vir verdere besinning (Handelinge, 1970:780).

In sy verslag aan die Algemene Sinode van 1974 verwys die KLPA na die vertolking van die aard van die drie besondere ampte (leraar, ouderling en diaken) in die lig van bepaalde Skrifgedeeltes in verslae wat voor die GES gedien het. In sy beredenering van die vraag oor die toeganklikheid van die besondere ampte vir vroue kom die KLPA tot die slotsom dat man en vrou gelykwaardig in status voor Christus is, dat vroue nietemin op grond van God se skeppingsorde in huis en gemeente aan mans onderdanig moet wees, maar dat hulle unieke funksies in die gemeente kan vervul (Handelinge, 1974:105-7). Na heelwat meningsverskil hieroor tydens die bespreking deur die Algemene Sinode, vereenselwig die Sinode hom tog met die KLPA se aanbevelings, naamlik (1) dat vroue op grond van die Bybel uitgesluit is van die ampte van leraar en ouderling, (2) dat vroue in die afwesigheid van duidelike uitsluitsel daaroor in die Skrif nie sonder meer tot die diakenamp toegelaat word nie, maar (3) dat die KLPA, soos deur die GES versoek, voortgaan om oor die kwessie van die vrou in die amp te besin en dié ondersoek uitbrei om oor die vrou in samelewing en kerk te handel (Handelinge, 1974:107, 575).

By die Algemene Sinode van 1978 lê die Algemene Kommissie vir Leer en Aktuele Sake (AKLAS), wat die KLPA intussen vervang het, twee verslae as bylaes tot sy aanbevelings voor. In die eerste bylae oor die vrou in die amp word verdere stawende argumente, gebaseer op Skrifgetuienis, aangevoer ter ondersteuning van die standpunte wat reeds by die vorige Algemene Sinode aanvaar is (Agenda, 1978:272-275). Die tweede bylae fokus spesifiek op die vraag "of die amp as amp prinsipieel geslote ... vir die vrou [beskou word]". Die besondere ampte word ontleed aan die hand van Skrifgegewens en van die geskiedenis van die rol van die vrou in die Christelike kerk. Daar word gewys op die situasie in 1978, naamlik dat verskeie WRK-lidkerke en selfs groot gereformeerde kerke in die Westerse wêreld vroue reeds tot die ampte van diaken, ouderling en selfs leraar toelaat. Die vroeëre konsensus onder gereformeerde kerke dat die vrou nie tot die besondere ampte toegelaat kan word nie, het dus verval. Daar word tot die gevolgtrekking gekom dat die beskikbare gegewens nie finale uitsluitsel gee oor die kwessie van die vrou in die amp nie. Daar word gemaan dat 'n balans gehandhaaf moet word deur die onderskeid tussen mans en vroue nie op te hef nie, maar ook nie te verabsoluteer nie (Agenda, 1978:276-282). 
By gebrek aan finale uitsluitsel het AKLAS aanbeveel dat die bylaes vir verdere besinning na die streeksinodes verwys moes word en dat die sinodes so gou moontlik studiestukke en aanbevelings aan AKLAS moes deurstuur met die oog op verslaglewering aan die volgende Algemene Sinode (Agenda, 1978:220). Die gedagte was om 'n omvattende beleidstuk oor die kwessie op te stel (Agenda, 1978:272). AKLAS se aanbevelings is na lang bespreking deur die Algemene Sinode aanvaar. 'n Amendement dat vroue intussen tot die diakenamp toegelaat word, is verwerp, maar die amendement dat vroue as diakonesse kon hulp verleen, maar nie as diakens bevestig mag word nie, is aanvaar (Handelinge, 1978:837-838)

Die kwessie oor die vrou in die amp was nou reeds meer as 'n dekade by sinodes van die NGK ter tafel sonder dat enige merkbare vordering na die een of ander kant gemaak is. Uit tradisionalisties-fundamentalisties konserwatiewe kringe in die patriargale bestuurstelsel van die NGK was daar steeds halsstarrige verset teen die verandering van die status quo. Een van die leidende fundamentaliste, wat in die sestiger- en sewentigerjare sy konserwatiewe stempel deeglik op die NGK afgedruk het, was dr. Koot Vorster. Dit was juis sy amendement teen die bevestiging van vroue as diakens wat by die 1978-sinode aanvaar is. 'n Letterlike interpretasie van Skrifuitsprake het hom tot die oortuiging gebring dat God nie die vrou geroep het om in die besondere ampte te staan nie. Die vrou moes in die gemeente nie 'n minderwaardige nie, maar 'n andersoortige rol as die man speel. Hy het die voorstanders van die vrou in die amp se "moderne eksegese" afgewys as 'n poging on die Woord van God tydgebonde te maak en te relativeer (Kerkbode, 28.10.81 en 13.01.82). Die vraag ontstaan egter of dit nie juis die vasklou aan apostoliese gebruike deur tradisionaliste was wat die Woord tydgebonde gemaak het nie.

Tolmie vat die fundamentalistiese standpunt soos volg saam: "Nooit mag ' $n$ argument wat begin met 'waarskynlik' ... lei tot die negering van beginseluitsprake nie ... Nooit mag die situasie waarin ons is, lei tot die relativering van die Skrifwaarhede (of Skrifinleg) nie. Nee, ook in die Ruimte-eeu moet gebuig word voor die finale gesag van die Woord!" (Tolmie, 1982:27). Die fundamentalistiese "nee" en "nooit" het nie vir die veranderlikheid van menslike oortuigings voorsiening gemaak nie

In die Afrikaanse suster- en dogterkerke van die NG Kerk is intussen ook debat gevoer oor die kwessie van die vrou in die besondere ampte. Die Gereformeerde Kerke in Suid-Afrika het besluit on nie vroue in die ampte toe te laat nie (Nadel, 1985:36). Daarenteen het die Nederduitsch Hervonnde Kerk in Afrika vroue in 1973 as diakens en in 1979 as ouderlinge en leraars toegelaat (Nadel, 1985:3436). Ook die NG Sendingkerk het vroue in 1978 as diakens (Nadel, 1985:37-38) en in 1982 (Kerkbode, 3.11.82) in die ander twee ampte aanvaar. 
Figuur 1

\begin{tabular}{|c|c|}
\hline \multicolumn{2}{|c|}{$\begin{array}{l}\text { Tradisionalisme vs. modernisme in die NGK: } \\
\text { Standpunte oor die vrou in die amp }\end{array}$} \\
\hline $\begin{array}{l}\text { Die modernistiese standpunt } \\
\text { (oorheersend sedert 1980) }\end{array}$ & $\begin{array}{c}\text { Die tradisionalistiese standpunt } \\
\text { (oorheersend tot 1980) }\end{array}$ \\
\hline $\begin{array}{l}\text { "In die besinning rondom die vrou en } \\
\text { die amp mag ons nie uitgaan van 'n } \\
\text { verstarde amptelikheid nie ... Die kerk } \\
\text { moet soek na die weë en middele om } \\
\text { die vrou na die eise van die tyd in haar } \\
\text { besondere aanleg, gawes en aard } \\
\text { diensbaar te maak aan die Koninkryk } \\
\text { van God." }\end{array}$ & $\begin{array}{l}\text { "Nooit mag die situasie waarin ons is, } \\
\text { lei tot die relativering van die } \\
\text { Skrifwaarhede (of Skrifinleg) nie. } \\
\text { Nee, ook in die Ruimte-eeu moet } \\
\text { gebuig word voor die finale gesag van } \\
\text { die Woord!" } \\
\text { (Francois Tolmie, 1982) }\end{array}$ \\
\hline $\begin{array}{l}\text { (Rapport ten gunste van die vrou in } \\
\text { die ouderling- en leraaramp, } \\
\text { Algemene Sinode 1986) } \\
\text { "As vroue in die twintigste eeu op elke } \\
\text { ander gebied hulle merk maak, } \\
\text { waarom ook nie op die kansel nie? } \\
\text { Legitimeer hulle gerus. Hulle kan die } \\
\text { kerk en die evangelie op 'n heel } \\
\text { spesiale manier dien." } \\
\text { (Dr. Piet Meiring, 1986) }\end{array}$ & $\begin{array}{l}\text { "Ons verwerp alle uitlegmetodes wat } \\
\text { beweer dat die boodskap van die Skrif } \\
\text { ook kultuurbepaald is en wat dan op } \\
\text { grond daarvan beweer dat in ons tyd } \\
\text { en kultuur ... die vrou ook in die } \\
\text { regeeramp van die kerk moet dien." } \\
\text { (Beswaarskrif van } 12 \text { NGK-leraars, } \\
\text { 1991) }\end{array}$ \\
\hline $\begin{array}{l}\text { "Indien ons die Bybel ernstig opneem, } \\
\text { kan dit nie anders nie: ons sal teen } \\
\text { enige vorm van diskriminasie teen en } \\
\text { verontregting van die vrou moet } \\
\text { wees." } \\
\text { (Dr. Adelbert Scholtz, 1992) }\end{array}$ & \\
\hline
\end{tabular}


Aan die einde van die sewentigerjare was die ou geslag tradisionaliste in die NGK-hiërargie op die pad uit. 'n Kentering het in die NGK se amptelike beskouing oor die vrou se posisie in die kerk en samelewing ingetree. 'n Nuwe geslag meer verligte manlike teoloë (daar was in daardie stadium nog min opgeleide Afrikaanse vroulike teoloë) het na vore getree. Hierdie geslag teoloë het tradisionalistiese beskouings bevraagteken. Hierdie jong geslag het die wesensgelykheid van die manlike en vroulike geslag erken - ondanks die verskille tussen die twee geslagte (Van Rensburg, 1987:122; kyk ook Handelinge, 1974:107; Agenda, 1978:282). Androsentrisme en misogenie in die kerk is verwerp (Van der Walt, 1987:120). (Figuur I dui die teenstellende tradisionalistiese en modernistiese standpunte in die NGK aan.)

Hierdie kentering was gebaseer op 'n nuwe interpretasie van Bybelse uitsprake wat voorheen ter regverdiging van manlike oorheersing gebruik is. Hierdie nuwe interpretasie het aangesluit by die histories-kritiese metode van Bybelondersoek 'n metode wat fokus op die sosiale, kulturele en historiese bepaaldheid van die teks (Van Deventer, 1990:5). Daar is gesê dat eeue-oue diepgewortelde vooroordele en stereotipes deur ' $n$ onbevange bestudering van die Bybel uitgeskakel kon word. Die Bybelse konsep van manlike hoofskap is geherinterpreteer om dit te onderskei van die konsep van gesag. Volgens die nuwe vertolking moet hoofskap nie met gesag, regering of heerskappy gelykgestel word nie, maar eerder met liefde en offervaardigheid geassosieer word. Eweneens moet onderdanigheid, soos deur die Bybel vereis, ook nie as sinoniem met gehoorsaamheid en minderwaardigheid beskou word nie (Van der Walt, 1987:105-14). Klem is deur die nuwe geslag NGK-teoloë gelê op Christus en die evangeliste se erkenning van die vrou se gelykwaardigheid met die man (Nadel, 1985:5-6; Scholtz, 1992:5; Koenig, 1993:9, Dippenaar, 1994:200).

Prof. Willie Jonker (1975:10) het tereg geskryf:

It is clear that the differences between those pro and contra the admission of women to the special offices boil down to a different approach to the way in which we should apply the relevant biblical data to our own time and in our own situation.

Die reformatories-filosofiese beginsel van soewereiniteit in eie kring van samelewingsverbande, waarvolgens elke verband sy eie gesagstruktuur het, is deur die jonger geslag meer verligte teoloë aangevoer as argument waarom die man se hoofskap in die luwwelik nie sonder meer op alle samelewingsterreine, byvoorbeeld die kerk, van toepassing gemaak kan word nie (Van der Walt, 1987:115, Buchner, 1991:8). Hiervolgens kan die getroude vrou enige gesagsposisie in kerk ell samelewing beklee wat nie in openlike botsing is met die aanvaarding van haar eie eggenoot se gesag oor haar bime die huwelik nie (Van Rensburg, 1987:123) 
Wat die vrou se posisie in die kerk betref, is Paulus se voorskrifte aan die vroeë Christelike kerk so geherinterpreteer dat dit vroue nie van volle deelname aan die erediens en van die bekleding van kerklike ampte uitgesluit het nie. Volgens die nuwe vertolking het vroue die reg gehad om op hul eie tipies vroulike wyse leiding in die kerk te gee (Scholtz, 1982:5, 15, Van der Walt, 1987:117-120). (Kyk figuur 2 vir die teenstellende interpretasies van Paulus se uitsprake.)

Figuur 2

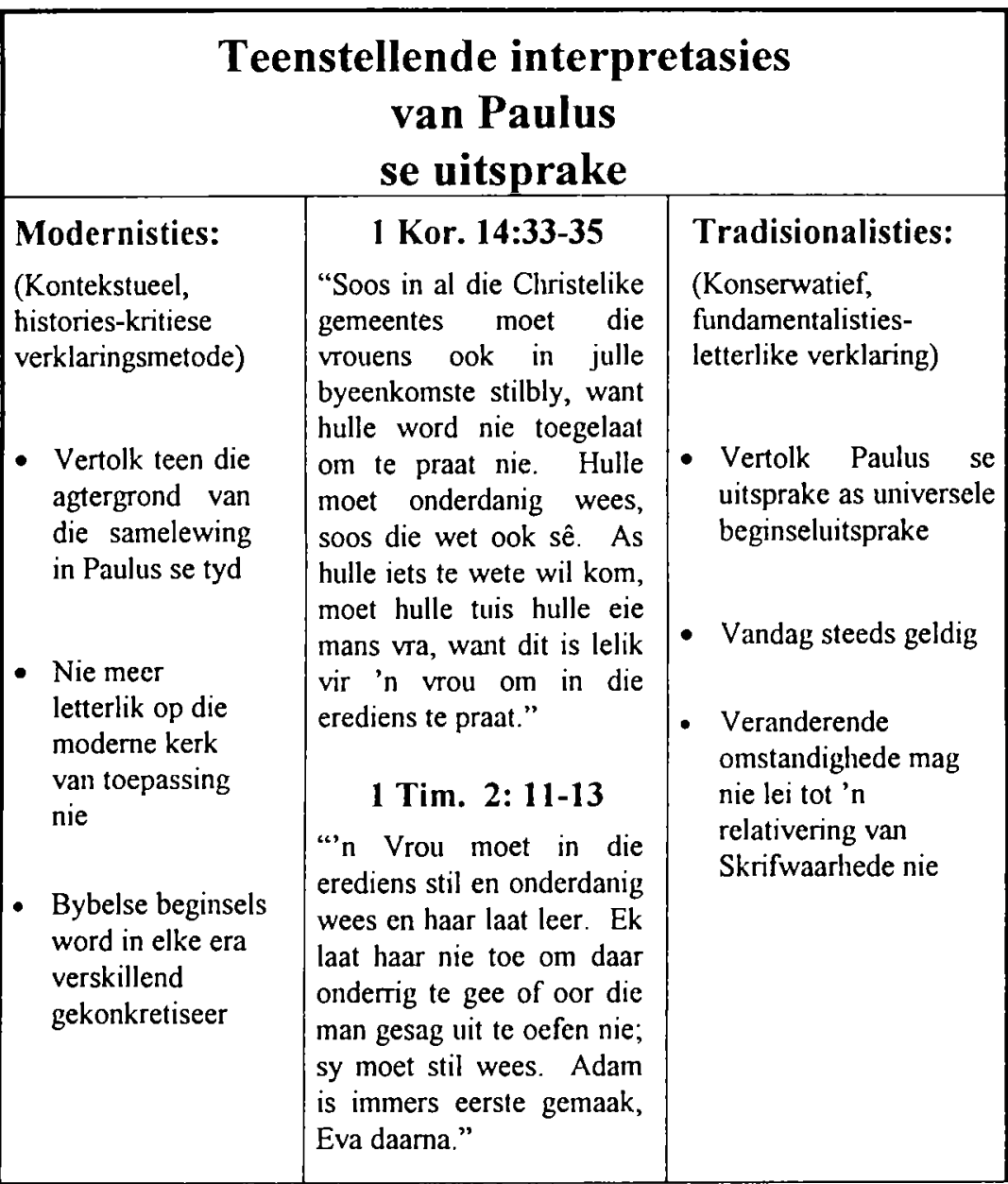


In die tagtigerjare sou konkrete voorwaartse stappe gedoen word om vroue tot die besondere ampte toe te laat. Voor die 1982-sitting van die Algemene Sinode was daar 'n polemiek in NGK-kringe oor die kwessie van die vrou in die amp. Prominente teoloë het hul toenemend ten gunste van die toelating van vroue tot die besondere ampte begin uitspreek. Hulle het aangevoer dat die argumente van diegene wat vroue op Bybelse gronde uit die ampte wou weer nie ' $n$ behoorlike eksegese van die betrokke Skrifgedeeltes kon deurstaan nie. Daar was voldoende getuienis dat vroue in die vroeë Christelike kerk in amptelike hoedanighede gedien het. Dit was trouens slegs tydens die Middeleeue dat daar nie vroulike ampsdraers in die kerk was nie. In die praktyk het talle vroue in die NGK reeds "amptelike" funksies as kategete, Bybelstudieleidsters en sieketroosters vervul (Scholtz, 1982:5, 15) Die vraag is gevra of manlike eersug nie in die pad staan van die oopstel van die diakenamp vir vroue nie (Kerkhode, 29.09.82. Brief, dr. M.T.S. Zeeman)

Tydens die 1982-sinodesitting was die kwessie oor die toelating van vroue tot die diakenamp een van die mees omstrede besprekingspunte. Uit die bylae van die AKLAS-verslag blyk dat een streeksinode (Noord-Transvaal), in opvolging van die 1978-sinode se versoek, besluit het dat vroue tot die amp van diaken toegelaat mag word. Twee streeksinodes (Oranje-Vrystaat en Midde-Afrika) het besluit dat die status quo gehandhaaf moet word en die ander streeksinodes het slegs kennis geneem, of die saak vir verdere oorweging verwys na sinodale kommissies (Agenda, 1982:518)

In sy beredenering van die saak het AKLAS aangedui dat die kern van die kwessie die hermeneutiese vraag was of Paulus in sy apostoliese uitsprake oor die posisie van die vrou in die gemeente algemene beginsels neergelê het, wat vir die kerk van alle tye geld, en of die beginsels wat neergelê is in verskillende tye verskillend gekonkretiseer kan word. Hieroor het in AKLAS meningsverskil bestaan; tog was daar ooreenstemming oor die moontlikheid dat vroue in die diakenamp mag dien. Daar was egter nie eenstemmigheid oor die vraag of vroulike diakens volle sitting in die kerkraad en dus volle deelname aan die kerklike regering moes hê nie (Agenda, 1982:520-3). AKLAS se aanbeveling was dat die diakenamp vir vroue oopgestel word en dat die hele kwessie rondom die besondere ampte verder op sinodale vlak ondersoek moes word (Agenda, 1982:461).

Die sinodegangers was in twee kampe verdeel oor hierdie aanbeveling. Verskeie amendemente is voorgestel. 'n Amendement dat die sinodebesluit van 1978 gehandhaaf moes word weens die moontlikheid dat die oopstelling van die diakenamp vir vroue tot die oopstelling van die ouderling- en leraaramp kon lei, is met 'n geringe meerderheid van 211 stemme teen 187 verwerp (Handelinge, 1982:1249). Prof. Johan Heyns, een van die leidende teoloë in die NGK wat in 
sy boek oor die dogmatiek die aanvullende gelykwaardigheid van man en vrou beklemtoon het (Heyns, 1978:hfst. 6: 4.4-5), se pleidooi ten gunste van die toelating van vroue tot die diakenamp was 'n invloedryke bydrae tot die debat. AKLAS se aanbeveling is aanvaar, maar na die Tydelike Regskommissie verwys vir advies oor die praktiese implementering van die oopstelling van die diakenamp (Handelinge, 1982:1252)

Volgens die Tydelike Regskommissie se aanbeveling het die sinodebesluit die diakenamp volwaardig vir vroue oopgestel en het dit nie die skep van 'n vierde amp vir diakonesse behels nie. Dieselfde verkiesingsprosedure, formulier en ampsbenaming sou vir manlike en vroulike diakens geld. Die sinodebesluit sou onmiddellik in werking tree en mindere kerkvergaderings (kerkrade, ringe en streeksinodes) kon self besluit oor praktiese aangeleenthede soos werkopdragte en kleredrag (Handelinge, 1982:1133-1134). Hierdie aanbeveling is ook deur die Sinode aanvaar, ondanks verbete pogings tot op die laaste deur tradisionaliste om die oopstelling van die diakenamp te verhinder (Handelinge, 1982:1392-1393, 1442).

In NG-kringe het 'n polemiek oor die oopstelling van die diakenamp vir vroue etlike maande voortgeduur. Argumente daarvoor en daarteen is in briewe en artikels in Die Kerkbode (26.01.83, 23.02.83, 2.03.83, 22.06.83, 4.07.84, 19.09.84) aangevoer. Publikasies oor die onderwerp het die lig gesien (o.a. Kleynhans, 1983).

Die oorgrote meerderheid NG-gemeentes het spoedig vrouediakens in toenemende getalle bevestig en vrouediakens (sommige van hulle ook in die posisie van leierdiaken) het 'n normale praktyk geword. Hulle het ook hul plek in kerkraadsvergaderings ingeneem en sodoende volwaardig deel aan die kerkregering verkry. Prakties het gemeentes daarby gebaat deurdat dankofferbydraes toegeneem het, die bediening in die wyke en in eredienste verbeter het en daar minder kworumprobleme by kerkraadsvergaderings was (Kerkbode, 7.09.83). By die Algemene Sinode van 1986 kon die Algemene Komitee vir die Vrouediens en AKLAS rapporteer dat vroue suksesvol in die diakenamp funksioneer (Agenda, 1986:161, 243)

In 1986 is die kwessie oor die vrou in die diakenamp finaal beslis. 'n Gravamen (beswaarskrif) van die Sinode van Suidwes-Afrika teen die toelating van vroue tot die diakenamp het in daardie jaar voor die Algemene Sinode gedien. Hierin is versoek dat die sinodebesluit van 1982, wat na bewering eerder op pragmatiese as Skriftuurlike gronde geneem is, ten gunste van die 1978-besluit hersien moes word en dat vroue nie langer as diakens toegelaat moes word nie. Alternatiewelik moes alle diakens van die kerkregering uitgesluit word (Agenda, 1986:465-487). Die meerderheid lede van die Tydelike Kommissie vir Leer en Aktuele Sake het bevind dat die gravamen geen nuwe insig bring wat die 
uitsluiting van vroue uit die diakenamp regverdig nie (Handelinge, 1986:541542). Op aanbeveling van die kommissie het die Sinode besluit on nie die gravamen te aanvaar nie (Handelinge, 1986:695-696). Die 1982-besluit oor die toelating van vroue tot die diakenamp is herbevestig en opdrag is aan AKLAS gegee om ondersoek in te stel na wyses waarop die vrou kragtens haar skeppingsmatige aard beter in die amp van diaken benut kan word (Handelinge, 1986:697). Sodoende is die laaste poging oin vroue uit die amp van diaken te weer, verydel.

\section{Vroue as ouderlinge en predikante toegelaat}

Voordat die stof oor vrouediakens gaan lê het, het stemme begin opgaan vir die oopstelling van die ouderlinganp vir vroue op grond van die eenheid en gelykwaardigheid van die ampte (Nadel, 1985:43). Teen die agtergrond van 'n emstige tekort aan manlike ouderlinge het die Ring van Pretoria in 1983 besluit om ' $n$ versoek aan die Algemene Sinode te rig dat vroue in die ouderlingamp toegelaat word waar dit werklik 'n behoefte is (Kerkbode, 7.09.83).

Kort voor die 1986-sinodesitting het die debat tussen die voor- en teenstanders van die toelating van vroue as ouderlinge aan momentum gewen. Soortgelyke teologiese en pragmatiese argumente is gebruik as in die stryd oor vrouediakens. In wese het dit weer gegaan oor teenstellende interpretasies van die Bybel in veranderende tye en oor die versoening van teorie en praktyk met mekaar.

Teenstanders teen die oopstelling van alle ampte vir die vrou het beklentoon dat ingrypende teologiese besluite nie op grond van praktiese oorwegings geneem kan word nie. Voorstanders het geantwoord dat die praktiese welsyn en bedieningsbehoeftes van gemneentes nie verontagsaan kan word nie en dat die anpte juis daar was ter wille van die opbou van die gemeente. Daar is gesê dat die verhouding tussen inan en vrou nie as 'n baas-knegverhouding beskou kan word nie, maar as 'n aanvullende verhouding. Daarom moes die vrou op haar eie wyse aanvullend betrokke wees by alle funksies en ampte van die kerk (Du Toit, 1986:3; Agenda, 1986:164-165).

By die Algemene Sinode van 1986 het die toelating van vroue tot die ouderlingen leraarsampte ter tafel gekom, maar die Sinode was klaarblyklik nog nie gereed on 'n finale beslissing te vel nie. Wat die 1982-sinode se opdrag dat die kwessie oor die vrou in die ampte verder ondersoek word betref, het AKLAS gerapporteer dat daar in AKLAS 'n staking van stemme oor die voorgestelde toelating van vroue tot die ampte van ouderling en leraar was. Daarom is twee rapporte, die een ten gunste daarvan en die ander daarteen, aan die Sinode voorgelê en is dit aan die Sinode oorgelaat on te besluit of vroue tot hierdie twee ampte toegelaat moes word (Agenda, 1986:160-168). Na bespreking het die Sinode 'n ordemosie aanvaar dat die kwessie vir verdere oorweging na die onderskeie sinodes verwys word. Terugvoering moes aan AKL.AS gegee word vir verslag aan die volgende 
Algemene Sinode (Handelinge, 1986:697). Vroue is dus voorlopig nog nie tot die ampte van ouderling en leraar toegelaat nie en die kwessie het op die NGK se agenda gebly.

Daar was gemengde reaksie op die Sinode se besluit om die toelating van vroue tot die twee ampte vir 'n verdere vier jaar te bevries (Kerkbode, 11.02 .87 en 4.03.87).

Na die 1986-Sinode is die debat tussen die voor- en teenstanders van vroue as ouderlinge en predikante in alle erns voortgesit. Voorstanders het aangevoer dat die omstandighede waarin Skrifbeginsels toegepas word, voortdurend verander (De Villiers, 1986:5) en dat selfs Paulus nie dogmaties was nie, maar hom in sy uitsprake deur plaaslike omstandighede laat lei het (Meiring, 1986:7). Hulle het beklemtoon dat mans en vroue gelykwaardig was, maar nie eenders nie, en dat die vrou kragtens haar eie aard in die ampte van predikant en ouderling moes dien (Büchner, 1991:9). Teenstanders was van mening dat die toelating van vroue as ouderlinge en leraars sou indruis teen die Goddelike skeppingsbeginsel ten opsigte van die verhouding tussen mans en vroue (Kleynhans, 1986:8).

In die loop van 1987 het die elf sinodes van die NGK die toelating van vroue as ouderlinge en leraars bespreek. Sewe sinodes het ten gunste van die toelating van vroue tot die ampte besluit en vier daarteen (Kerkbode, 28.10.87). Die sinodebesluite het tot hernude debat gelei oor die vraag of die Bybel "nee" sê vir vroue as predikante en ouderlinge (Kerkbode, 30.09.87, 21.10.87, 25.11.87). Namate die Algemene Sinode van 1990 nader gekom het, is hierdie debat geïntensiveer (Kerkbode, 10.02.89, 29.09.89, 19.01.90, 30.03.90)

AKLAS se verslag aan die Algemene Sinode van 1990 het in sy beredenering oor die voorgestelde toelating van vroue as ouderlinge en leraars verwys na talle vorige verslae waarin die kwessie eksegeties en dogmaties behandel is. Die meerderheidsverslag van AKLAS het die tersaaklike Skrifuitsprake en die praktiese situasie in die NGK ontleed en tot die gevolgtrekking gekom dat ondanks moontlike praktiese en kerkregtelike probleme daar geen Bybelse en teologiese gronde bestaan het waarom vroue nie tot die ouderling- en leraarsamp toegelaat mag word nie (Agenda, 1990: 128-131). In 'n minderleidsverslag van ds. Sampie van Vuuren is gevra dat in die lig van praktiese probleme wat met die bediening van vrouepredikante voorsien is, die rol van die vrou in die gemeente eers wetenskaplik ondersoek moes word alvorens 'n finale besluit oor die kwessie geneem word (Agenda, 1990:132). Beskrywingspunte deur streeksinodes, sommige ten gunste van die oopstelling van alle besondere ampte vir vroue en ander daarteen, het ook by dié Sinode gedien (Agenda, 1990:428)

Die aanbevelings van AKLAS se meerderheidsverslag is na afloop van ' $n$ lewendige debat wat deur prof. Johan Heyns afgesluit is, aanvaar in 'n stemming 
per geslote stembrief met 242 stemme teen 137. Vroue is dus tot die ampte van ouderling en leraar toegelaat. Gemeentes sou self kon besluit op watter wyse vroue as ouderlinge aangewend sou word. Moontlike kerkregtelike en praktiese knelpunte moes deur die Algemene Regskommissie ondersoek word en verslag daaroor moes aan die Algemene Sinodale Kommissie gelewer word. Aan die Algemene Kommissie vir Ampsbediening en Evangelisasie is opgedra om aanbevelings te maak oor die optimale funksionering van die vrou in die ampte van predikant en ouderling. 'n Beroep is op gemeentes gedoen om vroue met teologiese opleiding in diens te neem (Kerkbode, 26.10.90).

Met die besluit van 1990 dat vroue as ouderlinge en predikante bevestig kon word, is die stryd oor die toelating van vroue tot die besondere ampte, wat reeds in die sestigerjare begin het, uiteindelik afgehandel. (Figuur 3 bied 'n oorsig oor die Algemene Sinode se besluite oor die kwessie.)

Figuur 3

\begin{tabular}{|c|c|c|c|c|c|}
\hline \multicolumn{6}{|c|}{$\begin{array}{c}\text { Die vrou in die amp: } \\
\text { Besluite deur die NGK se algemene sinodes }\end{array}$} \\
\hline \multicolumn{3}{|c|}{$\begin{array}{c}\text { Tradisionalistiese } \\
\text { standpunt oorheers } \\
\text { (J.D. Vorster, E.P.J. Kleynhans, e.a.) }\end{array}$} & \multicolumn{3}{|c|}{$\begin{array}{c}\text { Modernistiese siening } \\
\text { word sterker } \\
\text { (J.A. Heyns, D. du Toit, } \\
\text { P. Meiring, A. Scholtz, e.a.) }\end{array}$} \\
\hline 1970 & 1974 & 1978 & 1982 & 1986 & 1990 \\
\hline $\begin{array}{l}\text { Vroue mag } \\
\text { nie ouderlinge } \\
\text { On predikante } \\
\text { word nie } \\
\text { - Moontlikheid } \\
\text { van vroue- } \\
\text { diakens na } \\
\text { KLPA } \\
\text { terugrerwys } \\
\text { virverdere } \\
\text { besinning }\end{array}$ & \begin{tabular}{|l} 
Vroue deur \\
Bybel \\
uitgesluit van \\
ampte van \\
leraar en \\
ouderling \\
- Nic Skrif- \\
tuurlike \\
uitsluitsel oor \\
vrouediakens \\
- KLPA noet \\
verder besin
\end{tabular} & $\begin{array}{l}\text { Shrifgegewens } \\
\text { gce nie finale } \\
\text { uitsluitsel oor } \\
\text { die vrou in die } \\
\text { amp nic } \\
\text { - Verwys na } \\
\text { sureeksinodes } \\
\text { vir oorweging- } \\
\text { hulpdiahonesse } \\
\text { goedgekeur }\end{array}$ & \begin{tabular}{|l|} 
- Die diaken- \\
amp vir v roue \\
oopgestel \\
- (211 icen 187 \\
stemme)
\end{tabular} & \begin{tabular}{|l} 
- Oopstelling \\
van diaken- \\
amp her- \\
bevestig \\
- Besluit oor \\
ander twce \\
ampte tor \\
volgende \\
sinode \\
uitgestcl
\end{tabular} & $\begin{array}{l}\text { - Vroue } \\
\text { toegelast tot } \\
\text { die ampte van } \\
\text { ouderling en } \\
\text { leraar } \\
\text { - (242 leen } 137 \\
\text { stemme) }\end{array}$ \\
\hline
\end{tabular}


Die Afrikaanse vrou se posisie in kerk en samelewing: evolusie van die NGK se standpumt

$\mathrm{Na}$ die besluit van die 1990-Sinode is vroue-ouderlinge algaande in al meer gemeentes verkies en bevestig, hoewel nie op dieselfde skaal as vrouediakens nie. In verskeie kerkrade was vrouediakens reeds in die meerderheid, terwyl vroueouderlinge in baie gemeentes 'n vreemde verskynsel was (Bezuidenhout, 1992:89).

Op 16 November 1990 is die eerste vier vroulike proponente in Pretoria as leraars gelegitimeer (Kerkbode, 23.11.90) en kort daarna is twee vroue in Stellenbosch en twee in Bloemfontein gelegitimeer (Kerkbode, 7.12.90). Dit was egter eers 'n paar jaar later, in Maart 1994, dat Gretha Heymans in Bloemfontein as die eerste vroulike predikant in 'n NG-gemeente georden en bevestig is (Kerkbode, 4.03.94)

Vanuit tradisionalistiese kringe was daar voortgesette protes teen die toelating van vroue tot die besondere ampte. Briewe en beswaarskrifte hieroor is in Die Kerkbode $(30.11 .90,14.12 .90,3.05 .91,17.05 .91)$ gepubliseer en by die streeksinodes van 1991 is ook besware geopper (Agenda, OVS 1991:502-506). 'n NGpredikant wat geweier het om vroue as ouderlinge en diakens te bevestig, is in 1992 geskors (Kerkbode, 11.12.92). Die stemme wat opgeklink het ten gunste van die herroeping van die sinodebesluite waardeur die besondere ampte vir vroue oopgestel is, het algaande meer geïsoleer geword.

\section{Die huidige posisie van vroue in die ampte in die NGK}

Volgens die jongste beskikbare amptelike statistiek was daar in 1993 ongeveer 1,3 miljoen lidmate in die NGK, waarvan $49,4 \%$ vroulik was (Olivier e.a., 1993:2, 15).

Statistiek toon aan dat vroue in al die streke goed aanvaar is in die diakenamp. Die persentasie vroulike diakens het stelselmatig toegeneem sedert vroue in 1982 as diakens toegelaat is. In 1985 was $9,3 \%$ van alle diakens vroue, in 1989 het dié syfer tot $21,6 \%$ en in 1993 tot 23,4\% gestyg (Olivier e.a., 1993:92). Waarskynlik meer as ' $n$ kwart van alle diakens in die NGK is vandag vroue. Die verkiesing van vroue as diakens het weliswaar nie die probleem van diakenvakatures opgelos nie, maar "dit word algemeen aanvaar dat die toelating van vroue tot die diakenamp 'n positiewe bydrae tot die kwaliteit van diakenswerk in die NGK gemaak het" (Olivier e.a., 1993:93). Hierdie verbetering word toegeskryf aan die feit dat vrouediakens oor die algemeen hul ampswerk met groter toewyding as mans uitvoer (Bezuidenhout, 1992:8).

$\mathrm{Na}$ alle waarskynlikheid sal die persentasie vroulike diakens verder styg, hoewel daar nie in die nabye toekoms pariteit met mans bereik sal word nie. 'n Belemmerende faktor is dat vrouediakens (soos trouens ook vroulike ouderlinge en predikante) 'n dubbele werklading het, aangesien hulle die werk van sowel die 
diaken (maandelikse dankofferinsameling, kerkraadsvergaderings, ens.) en die diakensvrou (kerkraadsvrouevergaderings, vroue-aksie, ens.) moet doen. Dit maak die diakenamp minder aantreklik vir beroepsvroue.

Vroue is veel stadiger tot die amp van ouderling verkies. In die tradisioneel patriargale Afrikaanse gemeenskap bestaan nog 'n wisselende mate van weerstand teen die opname van vroue in gesagsposisies. Veel meer as die diakenamp word die ouderlingamp as 'n regerende amp in die kerk beskou. Drie jaar na die toelating van vroue as ouderlinge (1993) was nog slegs $5,2 \%$ van alle ouderlinge vroue (Olivier e.a., 1993:93). In hierdie stadium is dit weens 'n gebrek aan vergelykende syfers nie moontlik om toekomstige tendense ten opsigte van vroue-ouderlinge te voorspel nie. Rapporte dui daarop dat die meeste vroulike ouderlinge op kerkraadsvergaderings nog huiwerig is om hul stem ten volle te laat hoor in die besluitnemingsproses (Bezuidenhout, 1992:9; Liebenberg, 1994:6). Desnieteenstaande het vroue in 1994 vir die eerste keer die Algemene Sinode as afgevaardigdes bygewoon (Algemene Kerkbode, 11.11.94) en sal hulle ongetwyfeld vorentoe sterker op die terrein van kerklike besluitneming figureer.

Navrae by die drie teologiese opleidingsentra van die NGK (wat namens die outeur deur mev. Christa Botes van die NG Kerkargief in Bloemfontein gedoen is) het aan die lig gebring dat 31 vroulike proponente sedert 1990 gelegitumeer is. Hierdie gegewens verteenwoordig heelwat minder as $10 \%$ van die studente aan hierdie instansies wat in hierdie periode hul teologiese studies voltooi het. Van hierdie 31 vroue staan slegs een tans voltyds in die bediening as 'n predikant. Twee vroue is in die sogenaande tentmakerbediening in gemeentes werksaam. Ongeveer die helfte van die ander is deeltyds in sinodale of gemeenteverband as proponente werksaam. Hulle doen onder meer studentebearbeiding, verpleegstersbediening, pastorale terapie, huweliksberading, hospitaalbesoek en radiowerk. Die ander is getroud of studeer voltyds verder of is werksaam buite kerklike verband

Vyf jaar na die toelating van vroue tot die leraarsamp is daar dus nog slegs een voltydse vroulike predikant in die NGK. 'n Soortgelyke tendens bestaan in die Nederduitsch Hervormde Kerk, waar 'n dekade na die oopstelling van die leraarsamp net vier voltydse vroulike predikante aan gemeentes verbonde was (Buchner, 1991:2). Hierdie situasie kan grootliks aan die ooraanbod van proponente vir die klein hoeveelheid vakatures vir predikante toegeskryf word. In die afgelope vyf jaar is baie min van die proponente wat aan die NGK se teologiese opleidingsentra afgestudeer het, na gemeentes beroep. Sowat 200 proponente wag tans vir beroepe na gemeentes.

Selfs al sou die aantal beskikbare predikantsposte verneerder, sal vroulike proponente nie op 'n gelyke voet met hul manlike kollegas om betrekkings kan 
Die Afrikaanse urou se posisie in kerk en samelewing: evolusie van die NGK se standpunt

meeding nie. Die meeste gemeentes verkies steeds om 'n man eerder as 'n vrou as predikant te beroep. Dit kan enersyds aan praktiese oorwegings toegeskryf word. Vrae soos die volgende word gestel: Sal 'n getroude vroulike predikant nie 'n botsing tussen haar beroep en die uitvoering van haar pligte as eggenote en moeder ondervind nie? Wie se beroep moet voorkeur kry indien 'n vroulike predikant na 'n ander gemeente beroep word of indien haar man verplaas word? Sal swangerskappe nie 'n vrouepredikant se bediening benadeel nie? (Buchner, 1991:16-18). Andersyds bestaan daar steeds vooroordele teenoor vrouepredikante, veral onder tradisionalisties-georiënteerde predikante, kerkraadslede en lidmate. Die faktore wat vroue se beroepsgeleenthede as predikante benadeel, is oorblyfsels van 'n patriargale sisteem wat nie oornag sal verdwyn nie.

Vroue in die NGK wat teologiese studie anpak, is bewus van die feit dat die toekoms vir die vrou as NG-predikant onseker is en dat hul kans skraal is om 'n gemeenteleraar te word. Teenstanders van die oopstelling van die leraarsamp vir vroue het trouens reeds voor en tydens die Algemene Sinodesitting van 1990 gewaarsku dat die toelating van vroue as predikante slegs simboliese waarde sou hê en valse verwagtinge by vroulike teologiestudente kon skep (De Klerk, 1989:6; Agenda, 1990:132).

Ondanks die probleme waarmee hulle gekonfronteer word, beklemtoon vroulike teologiese studente en gelegitimeerdes dat hulle ' $n$ roeping as bedienaars van God se Woord het wat hulle nie mag versaak nie. Hulle strewe almal daarna om 'n gemeentepredikant te word, aangesien hulle Woordverkondiging beskou as die hoogste taak van 'n predikant, en dit is waarvoor hulle sewe jaar lank gestudeer het. Dosente aan teologiese kweekskole bly oortuig dat vroulike predikante die teologie, die kansel en die pastoraat met hul eiesoortige aanslag kan verryk (Polumnia, Nov. 1993).

Die huidige posisie in die NGK is dus dat, hoewel vroue teoreties vrye toegang tot al drie besondere ampte het, daar in die praktyk nie sprake van gelykheid is nie. 'n Betreklik groot getal vroue dien reeds in die "junior" amp van diaken, maar min vroue is nog in die "senior" amp van ouderling in 'n regerende hoedanigheid ingeskakel. In die amp van leraar, wat onteenseglik steeds die spil is waarom die aktiwiteite in gemeentes sentreer, figureer vroue feitlik nog glad nie. (Figuur 4 bied 'n voorstelling van die huidige posisie van vroue in die besondere ampte in die NGK.) 


\section{Figuur 4}

Huidige posisie van vroue in die besondere ampte in die NGK (Uitgedruk in \% van poste beklee)

Diakens

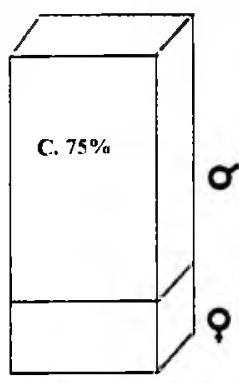

C. $25 \%$
Ouderlinge

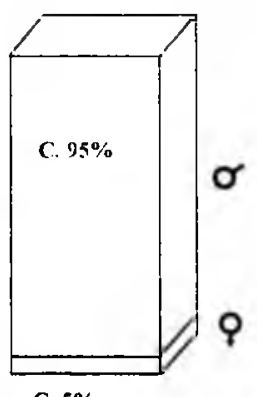

C. $5 \%$
Predikante

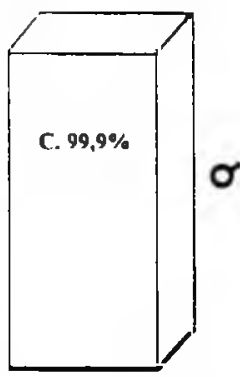

C. $0,1 \%$

\section{Gevolgtrekking}

Oor die afgelope dekades het die vrou se posisie en aansien in die NGK aanmerklik verander weens die oopstelling van die ampte van diaken, ouderling en predikant vir vroue Dit was die resultaat van 'n lang en moeisame stryd wat met sielewroeging vir die deelnemers gepaard gegaan het, maar gelukkig in 'n gees van Christelike naasteliefde gestry is. Watter boodskap het in die proses na lidmate en buitestaanders oor die siening van die NGK ten opsigte van die vrou se posisie in kerk en samelewing uitgegaan?

Eerstens het die debatvoering en sinodebesluite oor die kwessie van die vrou in die amp 'n verskuiwing in die NGK-leiding weg van tradisionalistiese fundamentalisme na 'n minder dogmatiese benadering aangetoon.

Daar was deurgaans en is steeds binne die NGK verskeie nuanses in die beskouing oor die vrou se status en rol. Aan die tradisionalistiese kant word geredeneer dat dit 'n skeppingsbeginsel van God is dat die man as hoof oor die vrou aangestel is en hy dus in die gesin, die kerk en ander samelewingsverbande 
'n gesagsposisie beklee waaraan die vrou haar in onderdanigheid moet onderwerp. Hierdie verordineerde gesagsverlouding het 'n stabiliserende invloed op die samelewing. Volgens die tradisionaliste is die vrou se primêre lewenstaak om as huweliksmaat vir haar man en moeder vir haar kinders op te tree. Die vrou se plek is dus na regte in die huis. Indien die man sy gesag uitoefen en die vrou haar huislike pligte uitvoer, glo die tradisionaliste dat baie probleme van die moderne samelewing uitgeskakel kan word. Hulle wil die tradisionele differensiasie tussen die posisie, rol en funksie van die man en die vrou in die samelewing handhaaf. In die hedendaagse samelewing word dié differensiasie bedreig deur humanisties-liberalistiese invloede wat alle onderskeide tussen man en vrou probeer ophef.

Die tradisionalistiese konsep van die gesagsverhouding tussen mans en vroue is nie tot mans beperk nie. Afrikaanse vroue is oor 'n baie lang tydperk gekondisioneer tot onderdanigheid. 'n Markinor-meningsopname in 1984 het bevind dat Afrikaanse vroue die grootmaak van kinders en tuisteskepping as hul primêre taak beskou en dat hulle minder as Engelssprekende vroue op selfvervulling en selfrespek ingestel is (Pretoria News, 30.10.84). Volgens Denise Ackernann (1994:22) figureer die Protestantse konsep dat die vrou se plek in die huis is en dat dit deel is van 'n Goddelik verordineerde skeppingsorde, nog steeds as ' $n$ dominante mite onder blankes en veral Afrikaanssprekendes.

Teenoor die tradisionalistiese uitgangspunt ervaar diegene met 'n meer modernistiese siening die emansipasie van die vrou op alle terreine as 'n positiewe tendens waardeur die eeuelange onregnnatige en chauvinistiese diskriminasie teen vroue opgehef word. Hulle verwerp die tradisionaliste se gesagsbegrip in die verhouding tussen man en vrou as wetties, fundamentalistiesbiblisties en selfs sekulêr Die man se skeppingsgefundeerde "hoofskap" is hoogstens leierskap op bepaalde terreine, nie heerskap op alle terreine nie. Man en vrou vervul gelykwaardige, aanvullende rolle. Dit was juis die Christendom wat gehelp het om die vrou te bevry binne die huwelik en op ander terreine. Die Christenvrou is haar man se kameraad eerder as sy ondergeskikte. Vroue het die reg om hulself buite die huis - in die kerk, die beroepslewe en ander samelewingsverbande - ten volle uit te leef en om na gesagsposisies te aspireer.

Die gemene deler tussen dié opponerende beskouings in kerklike kringe is dat albei die gelyke status van man en vrou voor God in die amp van die gelowige erken en dat hulle radikaal-feministiese pogings om alle natuurlike onderskeide tussen die geslagte op te hef afwys.

Tot diep in die sewentigerjare was die tradisionalistiese standpunt oorheersend in die NGK-hiërargie. Sedertdien het die posisie omgekeer en voer die modernistiese siening toenemend die botoon. Dit word duidelik weerspieël in die 
agtereenvolgende Algemene Sinodes tussen 1970 en 1990 se hantering van die kwessie oor die vrou in die besondere ampte.

Die tweede hoofgevolgtrekking wat gemaak kan word, is dat daar steeds in die NGK 'n groot gaping tussen teorie en praktyk bestaan ten opsigte van die status van die vrou - soos ook in ander Christelike kerke. Hoewel vroue geruime tyd reeds teoreties gelyke status met mans ten opsigte van die beklee van kerklike ampte geniet, is daar in die praktyk nog weinig sprake van gelykheid. In kerklike vergaderings (kerkrade, ringe, streeksinodes en algemene sinodes) is vroue nog hopeloos onderverteenwoordig en in die invloedrykste amp, diè van predikant, figureer vroue kwalik. Ackermann (1994:28) stateer tereg: "Leadership, power and authority in the white Afrikaans-speaking churches are safely in male hands, despite certain recent decisions by some to open church offices to women."

Vrese wat uitgespreek is dat die NGK al meer 'n "vrouekerk" gaan word (Kerkbode, 4.05.88) en dat mans deur vroue in kerkrade verdring kan word (Bezuidenhout, 1992:9), skyn in hierdie stadium vergesog te wees. Prof. Christina Landman kla dat die kerk nie na vroueteoloë luister nie en dat vroue nie in aanmerking geneem word vir kerklike leiersposisies nie (Kerkbode, 4.03.94). Vroue in amptelike posisies in die kerk ondervind selfs teenkanting en vyandigheid van ander vroue (Kerkbode, 18.02.94). Volgens haar sien vroue die beklee van anpte en leiersposisies in die kerk nie as deel van ' $n$ inagstryd teen mans nie, maar voel hulle hul ook geroepe om die koninkryk van God te dien (Kerkbode, 11.02.87).

Die huidige status van vroue in die NGK, in teorie en praktyk, weerspieël enersyds waarskynlik nie so 'n piëtistiese onderdanigheid van Afrikaanse vroue soos wat Landman in haar boek skets en soos wat feministe beweer nie. Die situasie in die NGK verskil trouens nie wesenlik van dié in ander Protestantse kerke in Suid-Afrika en die buiteland nie. Andersyds is dit duidelik dat eeue van patriargale oorheersing nie oornag ongedaan gemaak kan word nie. Daar lê nog 'n opdraande pad voor alvorens vroue praktiese gelykheid in die hiërargie van die NGK en ander Christelike kerke sal geniet. Christelike kerke het gevorder op die pad na demokratisering, deelname en verantwoordbaarheid, maar aan die feministiese oproep tot 'n totaal nie-seksistiese kerkmodel (Ackermann, 1994:27) sal nie maklik voldoen word nie.

\section{Literatuurlys}

ACKERMANN, D 1994. Context, challenge and change; perspectives on women in South Africa. (II Institute for Reformational Studies. Women in Africa. Potchefstroom IRS/PUCHE. p. 12-35) 
Die Afrikaanse vron se posisie in kerk en samelewing: evolusic van die NGK se standpum

AGENDA 1970, 1974, 1978, 1982, 1986, 1990. Agendas vir die derde (Pretoria), vierde (Kaapstad), vyfde (Bloemfontein), sesde (Pretoria), sewende (Kaapstad), agste (Bloemfontein) vergaderings van die Algemene Sinode van die Nederduitse Gereformeerde Kerk

AGENDA OVS 1991. Agenda van die Vrystaatse Sinode van die Nederduitse Gereformeerde Kerk, Bloemfontein.

BAKTIS, P.A. 1992 The Dublin statement and women's ordination. Journal of Ficumenical Studies, 29(1):35.

BEZUIDENHOUT, N. 1992. Verdring die vrou die man in die kerk? Die Kerkbode, 149(23):8-9, Jun. 26.

BUCHNER, E.P. 1991. Die vrou as predikant: enkele konsekwensies in die gereformeerde bediening. Bloemfontein : UOVS. (B.Theol-skripsie.)

CILLIERS, C. 1994 Resensie van Christina Landman The piety of Afrikaans women. Insig 3-4, September (Bylaag)

CLOETE, E. 1992. Afrikaner identity culture, tradition and gender, Agenda, 13:42-56

CYRE, S. 1994 Fallout escalates over 'goddess' Sophia worship. Christianity Today, 38(4) 74, April 4

DE KLERK, M. 1989 Vrou as leraar? - Die Bybel sê nie so nie Die Kerkbode, 143(5):6, Feb. 10

DE VILLIERS, I 1986 As 'n vrou preek. Die Kerkhode, 138(23) 5, Des. 3

DIPPENAAR, M.C 1994 Gelykheid tussen mans en vroue in die geskrifte van Lukas Ned Geref Teologiese Tydskrif, 35(2):200-210, Jun. 2.

DU PISANI, J A. 1994. Negotiating a democratic South Africa: Bilateral and multiparty negotiations, June 1992 to December 1993 Joernaal vir Eietydse Geskiedenis, $19(2): 28-81$

DU TOIT, D 1986 Die vrou as predikant, ouderling? - hieroor verskil ons nog. Die Kerkbode, 138(12) 3, Sep 17.

FERREIRA, M 1993. Feministiese teologie 'n kritiese evaluering van Hosea 2. Bloemfontein : UOVS. (B.Theol.-skripsie.)

FINDLEY, C.V \& ROTHNEY, J A M 1990. Twentieth-century world Boston : Houghton Mifflin

FRAME, R 1994 Vote overturns women's ordination Christiamity Today, 38(9):52, Aug 15.

GNANADASON, A 1994. Editorial. The Ecumenical Review, 46(2):133-134, April

HAMBIDGE, J Op my literêre sofa Beeld, 4.08.94.

HANDELINGE 1966,1970, 1974, 1978, 1982, 1986, 1990. Handelinge van die derde vierde, vyfde, sesde, sewende, agste vergadering van die Algemene Sinode van die Nederduitse Gereformeerde Kerk

HEYNS, J A 1978 Dogmatiek Pretoria : NG Kerkboekhandel

HEYWOOD, A. 1992. Political ideologies; an introduction. Houndmills, Basingstoke Macmillan

KERSTEN, K. 1994. How the feminist establishment hurts women. Christianity Foday, 38(7):20-5, Jun. 20

KLEYNHANS, E P.J 1983 Die vrou en die amp in die NG Kerk Bloemfontein : UOVS.

KLEYNHANS, E.P J 1986 Vroue-predikante: wat sou Paulus sê? Die Kerkbode, 138(23) 8, Des 3

KOENIG, A. 1993 Vrou as leier in die kerk volgens Markus. Die Kerkbode, 152(23):9, Des. 17

LANDMAN, C. 1994 The piety of Afrikaans women, diaries of guilt Pretoria : Institute for Theological Research, Unisa 
LIEBENBERG, R 1994 Gretha Heymans mak nuwe deure vir die vrou as gemeentepredikant oop. Dic Kerkbode, 153(7):6, Mrt. 4.

MEIRING, M. 1994. Afrikaanse mans se 'komplot' teen die vroue. Insig. 17-18, Aug

MEIRING, P. 1986. Vroue-predikante: wat sou Paulus sê? Die Kerkbode, 138(20)7, Nov 12.

MOODY, J. 1994. Just saying no to women. Time, 143(24):49, Jun. 13.

MORGAN, T.C. 1994. The stained-glass ceiling. Christianity Today, 38(6):52, May 16

MORROW, L, 1994. A convert's confession Time, 144(14):60, Oct. 3

MULLER, J. 1994. Vroue op die preekstoel. Die Kerkbode, 153(7):11. Mrt. 4

NADEL, B.A. 1985. Die posisie van die vrou in die kerk met betrekking tot die ampte Bloemfontein : UOVS (B.Th.-skripsie)

OLIVIER, G.C., e.a. (reds.) 1993. Kerkspieël IV. Verslag van die vierde wetenskaplike opname van die Ned. Geref. Kerk in Maart 1993 in opdrag van die Algemene Sinode. Pretoria.

OPOCENSKA, J 1989. Women and the conciliar process. Reformed World, 40(7):142-147, Sept.

OSTLING, R.N. 1992. The second reformation Time, $140(21): 48-54$, Nov. 23

OSTLING, R N. 1994. Romeward bound Time, 143(8):48-9, Feb 21

SCHOLTZ, A. 1982. Vroue in die kerkraad. Die Kerkbode, 130(6) 5, 15 , Aug. 11.

SCHOLTZ, A. 1992. Vrou kan nie man se rol oorneem nie, maar hulle is gelyk. Kerkbode, 149(9):5, Mrt. 13

SCHÜSSLER-FIORENZA, E. 1994/5 Women's religious studies ignored. CSD Bu/letm, 1(8): 13, December/January

STAVRIANOS, L.S. 1990. The world since 1500. A global history. Englewood Cliffs, N.J. : Prentice-Hall

STEYN, D 1994. Vroue ondergrawe mans al jare lank Ins/g 12-13, Junie

TOLMIE, F. 1982. Die vrou in die diakenamp? Dic Fakkel, 2:25, 27.

VAN DER WALT, B 1987. Verrassings vir die vrou uit die Nuwe Testament (In Instituut vir Reformatoriese Studie. Venster op die vrou. Potchefstroom : IRS/PUCHO p. 98120.)

VAN DEVENTER, L. 1990. Die vrou as leraar, ouderling ... wat sê die Bybel regtig? Die Kerkbode, 145(2):5, Jan. 19

VAN RENSBURG, F.J. 1987. Selfbevryders: die kerklik verontregte vrou se eie plig en verantwoordelikheid ten opsigte van haar verontregting. (III Instituut vir Reformatoriese Studies. Venster op die vrou. Potchefstroom : IRS/PUCHO. p 121-131.)

VAN WYK, A. 1987. Moet ons God as manlik voorstel? In gesprek met die feministiese teologie. (In Instituut vir Reformatoriese Studie. Venster op die vrou Potchefstroom : IRS/PUCHO p 69-79.)

WALLBANK, T.W. et al. 1981. Civilization past and present, vol. 2 th ed. Glenview : Scotı, Foresman \& Co.

WESSELS, C 1994. Onderdanig of selfgeldend? Sarie: 32-33, Okt. 26. 